\title{
Ação Coletiva e Delegação de Poder no Semiárido Nordestino: papel de lideranças locais e assessores externos numa comunidade rural ${ }^{1}$
}

\author{
Maria Odete Alves², Marcel Bursztyn ${ }^{3}$ e Suely Salgueiro Chacon ${ }^{4}$
}

Resumo: Este artigo analisa a experiência coletiva que se desenvolve desde meados dos anos 1980 na comunidade rural de Lagoa dos Cavalos (Russas, Ceará), no Semiárido nordestino, cujas terras são resultantes de partilha por herança, e onde se registra uma forma peculiar de organização que garante à população certa autonomia nas decisões coletivas sobre o desenvolvimento local. O objetivo é verificar a quem são delegados poder e responsabilidade no processo de coordenação da ação coletiva, seu perfil e seus papéis. Optou-se pela pesquisa qualitativa, combinando o uso de fontes testemunhais, documentais e bibliográficas. Utilizou-se a amostragem não probabilística intencional na definição dos atores entrevistados. A conclusão aponta que poder e responsabilidade são delegados a dois tipos de lideranças locais que detêm o reconhecimento e a legitimidade para o atendimento das demandas inerentes aos trabalhos de coordenação das atividades coletivas ou para mediação entre população local, assessores externos e o mundo, conservando relativa autonomia. Os assessores externos prestam apoio técnico e político, além de facilitarem o acesso a recursos financeiros. Ambos, lideranças locais e assessores externos, têm papel importante no desenvolvimento local. Mas são dependentes da organização local, que tem criado mecanismos que permitem construir a cooperação e a coordenação da ação dos atores envolvidos.

Palavras-chaves: Ação coletiva; delegação de poder; agricultura familiar; Nordeste brasileiro; Semiárido.

Abstract: This paper examines the collective experience developed since the mid 1980 in a rural community of Northeastern semi-arid region - Lagoa dos Cavalos (Russas, Ceará). The land tenure pattern is based on fragmentation by inheritance, and its formal registration

1. Data de submissão: 7 de março de 2014. Data de aceite: 28 de julho de 2015.

2. Escritório Técnico de Estudos Econômicos do Nordeste (Etene), Banco do Nordeste do Brasil (BNB). Fortaleza, CE, Brasil. E-mail: moalves1@gmail.com

3. Centro de Desenvolvimento Sustentável, Universidade de Brasília. Brasília, DF, Brasil. E-mail: marcel.cds@gmail.com

4. Universidade Federal do Cariri. Juazeiro do Norte, CE, Brasil. E-mail: suelychacon@gmail.com 
enables a peculiar form of organization that ensures the population certain autonomy in collective decisions on local development. The goal of this article is to check who has power and responsibility in the process of collective action coordination, the profile and the role of these actors. The method is based on qualitative research, combining the use of witness statements, documentary and bibliographical sources. Intentional non-probability sampling was used for the definition of the actors to be interviewed. The conclusion points that power and responsibility are delegated to two types of local leaders, who hold the recognition and legitimacy to meet the demands inherent in the work of collective activities coordination or for mediation between the location, the external advisors and the world, keeping on autonomy. The external advisors provide technical and political support, and facilitate the access to financial resources. Both local and external advisors leaders play an important role in local development, but are dependent on the local organization that has created mechanisms to build cooperation and coordination of action of those involved.

Key-words: Collective action; Power delegation; Family farmers; Brazilian semi-arid.

DOI - http://dx.doi.org/10.1590/1234-56781806-9479005303003

Classificação JEL: D71, D74, D79.

\section{Introdução}

Historicamente as organizações locais do Semiárido têm sido expostas ao risco de captura por oligarquias regionais ou locais. As fragilidades da população e, principalmente, a postura de dependência de determinadas lideranças locais em relação a tais oligarquias, têm contribuído para que as mesmas se apropriem dos benefícios do Estado. Nos dias atuais, tal apropriação pode acontecer sob novas formas de tutela oriundas de instituições públicas ou de entidades da sociedade civil e ligadas à igreja. Como consequências maléficas, destacam-se a manipulação da população local e a imposição da mentalidade do assistencialismo, do clientelismo e da dependência que a imobiliza.

Este artigo relata o caso da comunidade Lagoa dos Cavalo (Russas, Ceará), mostrando que é possível à população do Semiárido manter uma trajetória de desenvolvimento, com postura de relativa autonomia frente às forças externas, sejam oligarquias ou novas tutelas. A comunidade é resultante de um processo de fragmentação fundiária e exemplo de resistência aos processos de modernização capitalista sobre suas terras, com auge durante a implantação do projeto de irrigação Tabuleiro de Russas.

A resistência de Lagoa dos Cavalos está assentada na ação coletiva, cuja história de organização tem origem em meados dos anos 1980. Nesse percurso verificou-se inicialmente o surgimento de pequenos grupos informais com interesses comuns voltados para a viabilização da produção e de infraestrutura coletiva, nos quais articulam-se novas formas coletivas de uso e gestão com modos preexistentes de uso comunal dos recursos. Posteriormente, surgiram outros grupos, ligados a questões socioculturais, e se formalizou uma associação comunitária que se tornou uma espécie de guarda-chuva no processo de gestão dos espaços e recursos comuns, além de viabilizar o acesso ao crédito e a participação em redes e comissões de interesse local.

O fortalecimento da organização a partir dos grupos e o surgimento de lideranças asseguraram aos moradores a conquista histórica de reassentamento, dentro do projeto de irrigação ao invés da expropriação inicialmente proposta.

Como todas as atividades humanas, a ação coletiva em Lagoa dos Cavalos é produto de uma construção social que, por sua vez, requer um longo processo de organização. Ou seja, é dependente de um conjunto de mecanismos que estabilizam um ambiente potencialmente instável e conflitivo, permitindo construir a cooperação e a coordenação da ação que envolve atores com diferentes condutas (FRIEDBERG, 1993). Ou seja, por detrás do caráter aparentemente ordenado das ações coletivas exitosas encontram-se conflitos de racionalidades e de interesses, de concorrência e também alianças, remetendo à construção de relações de poder. 
Por sua vez, o exercício do poder, em contextos de ação locais, gera construções políticas e também regras, ou seja, requer regulação dos comportamentos dos atores envolvidos e, portanto, disciplina e negociação entre eles. Cria-se, assim, um espaço de aprendizagem individual e coletiva, pela criação e descoberta de novos recursos e novas capacidades que ajudarão na cooperação e na solução de conflitos (FRIEDBERG, 1993). Portanto, a coordenação da ação coletiva envolve o exercício do poder por delegação, mas também a aprendizagem e a regulação dos comportamentos dos atores, processos esses que, além de diversos e dinâmicos, acontecem simultaneamente.

Esta é uma temática pouco explorada e que, portanto, está por merecer avanços no debate acadêmico. O meio rural no Semiárido nordestino é lugar profícuo para descobertas científicas, em função da diversidade de experiências que aí se desenvolvem diuturnamente. Do ponto de vista das políticas públicas, estudos dessa natureza contribuem para o aperfeiçoamento de modelos de intervenção, na medida que ajudam a compreender as dinâmicas internas de experiências coletivas locais.

Com o intuito de contribuir para enriquecer o debate acadêmico sobre o tema e subsidiar a formulação de políticas públicas, o presente estudo identifica os atores com atribuição de representar os interesses coletivos locais na comunidade Lagoa dos Cavalos, seus perfis e respectivos papéis na coordenação da ação coletiva.

O texto está distribuído em quatro seções, além desta introdução e das considerações finais. A primeira seção expõe os procedimentos metodológicos adotados durante a realização do estudo. A segunda apresenta uma caracterização de Lagoa dos Cavalos, abordando os principais aspectos socioeconômicos e da organização local. A terceira discorre sobre a base teórica utilizada na análise do caso. A seção quatro analisa a delegação de poder em si, identificando os atores que exercem poder e responsabilidade, assim como seus respectivos perfis e os papéis exercidos na coordenação da ação coletiva.

\section{Procedimentos metodológicos}

Em função da necessidade de compreender e explicar as relações sociais na comunidade e por reconhecer nessa abordagem as condições mais apropriadas para a aproximação do objeto de pesquisa, optou-se pela pesquisa qualitativa para a realização deste estudo. $\mathrm{O}$ desenho geral combinou o uso de fontes testemunhais, documentais e bibliográficas, compreendendo um conjunto de procedimentos em etapas (Quadro 1), não necessariamente em sequência linear, pois em diversos momentos conduziram-se processos paralelos ou sobrepostos.

Em campo, coletaram-se as informações em dois momentos. Inicialmente, adotou-se a exploração com roteiros de entrevista aplicados a atores aleatórios, procedimento flexível que permitiu transitar por pontos de observação à medida que se avançava no conhecimento do objeto de estudo. Posteriormente, utilizou-se a entrevista individual não estruturada, valendo-se da gravação e das notas de campo. Em ambos os momentos, lançou-se mão também da observação simples, de conversas, materiais não oficiais e matérias em jornais, revistas especializadas, periódicos, livros e de outras fontes.

Quadro 1. Procedimentos de pesquisa

\begin{tabular}{|l|l|}
\hline \multicolumn{1}{|c|}{ Etapas } & \multicolumn{1}{c|}{ Atividades } \\
\hline Início & Identificação do objeto de pesquisa; definição da questão de pesquisa; revisão da literatura. \\
\hline Delimitação & Identificação dos limites do fenômeno a ser estudado. \\
\hline Em Campo & $\begin{array}{l}\text { Definição de técnicas; montagem dos instrumentos de coleta; pré-teste dos instrumentos de coleta; aplicação dos } \\
\text { instrumentos de coleta. }\end{array}$ \\
\hline Análise & $\begin{array}{l}\text { Identificação de categorias conceituais; compreensão das relações entre categorias; comparação das categorias } \\
\text { com proposições teóricas. }\end{array}$ \\
\hline Final & Elaboração do relatório final. \\
\hline
\end{tabular}

Fonte: Elaboração própria. 
412 - Ação Coletiva e Delegação de Poder no Semiárido Nordestino: papel de lideranças locais e assessores externos numa comunidade rural

A definição dos atores para entrevistas, no segundo momento, aconteceu durante a fase exploratória, utilizando-se da amostragem não probabilística intencional (COSTA NETO, 1977; MARCONI e LAKATOS, 1990; COUTINHO, 2011). Ou seja, optou-se pela escolha deliberada dos atores a partir do julgamento dos pesquisadores sobre quais fontes de informações seriam mais adequadas para fornecer contribuições que permitissem alcançar os objetivos do estudo.

Foram entrevistados 24 atores (14 moradores e 10 agentes externos / representantes de instituições externas), totalizando 32 entrevistas (quatro atores internos concederam duas entrevistas cada; dois atores internos concederam três entrevistas cada). As entrevistas foram realizadas durante os meses de abril de 2009, abril, maio, junho e setembro de 2010 e maio de 2012.

As informações coletadas por meio dos vários instrumentos tiveram seus conteúdos analisados e confrontados utilizando a técnica de triangulação de dados (TRIVIÑOS, 1987; CROLL, 1995; SOUZA e ZIONI, 2003). Além de permitir aprofundar a análise das informações obtidas a partir de diversas técnicas de coleta, a triangulação de dados permite estabelecer inter-relações entre as falas, as ações dos atores e os fatos (SOUZA e ZIONI, 2003). Isso facilita verificar tanto a coerência e consistência das informações quanto a compreensão do fenômeno a partir das diversas perspectivas.

A fim de preservar a identidade dos entrevistados, quando mencionados no texto, são representados por letras do alfabeto, podendo ser antecedidas dos termos "liderança" ou "líder", quando se tratar de líderes e do termo "informante", quando o depoimento for de outros entrevistados. No primeiro caso, as letras seguem a ordem de apresentação no texto; no segundo, seguem a ordem dos depoimentos.

\section{O território e a socioeconomia de Lagoa dos Cavalos}

O que aqui recebe a denominação Lagoa dos Cavalos é o conjunto de quatro pequenas comunidades rurais do sertão cearense (Lagoa dos Cavalos, Córrego Salgado, Junco e Barbatão), cujas características se assemelham ao definido por Ribeiro (1992): formam um território no qual mora e convive um conjunto de famílias de agricultores que têm proximidade por laços de parentesco, amizade e compadrio, apresentam condições socioeconômicas e culturais parecidas, realizam trocas materiais e não materiais e seguem determinadas normas negociadas e definidas pelos costumes. A adoção arbitrária do termo deve-se ao fato de ser Lagoa dos Cavalos a maior e mais conhecida em relação às demais.

Localizada na sub-bacia do Baixo Jaguaribe, Lagoa dos Cavalos se encontra a 22 quilômetros da sede do município de Russas $(160 \mathrm{~km}$ de Fortaleza). Situa-se nas proximidades da $1^{\text {a }}$ etapa do Perímetro Irrigado Tabuleiro de Russas (PITR) e onde está sendo implantada a $2^{2}$ etapa do mesmo perímetro de irrigação (Figura 1).

$O$ relato de moradores locais aponta que seria entre o início do século XX e os anos 1930 o período de formação dessa comunidade rural quando quatro famílias adquiriram terras e se estabeleceram no local: uma em Barbatão, duas no Córrego Salgado e uma no Junco.

Ao longo dos anos, essas famílias cresceram, principalmente pela realização de matrimônios cruzados entre seus membros nas diversas gerações. Por isso, atualmente o conjunto da população se caracteriza como uma rede de proximidade, envolvendo laços de parentesco, vizinhança e compadrio, além de certa homogeneidade socioeconômica. 
Figura 1. Localização da área de estudo

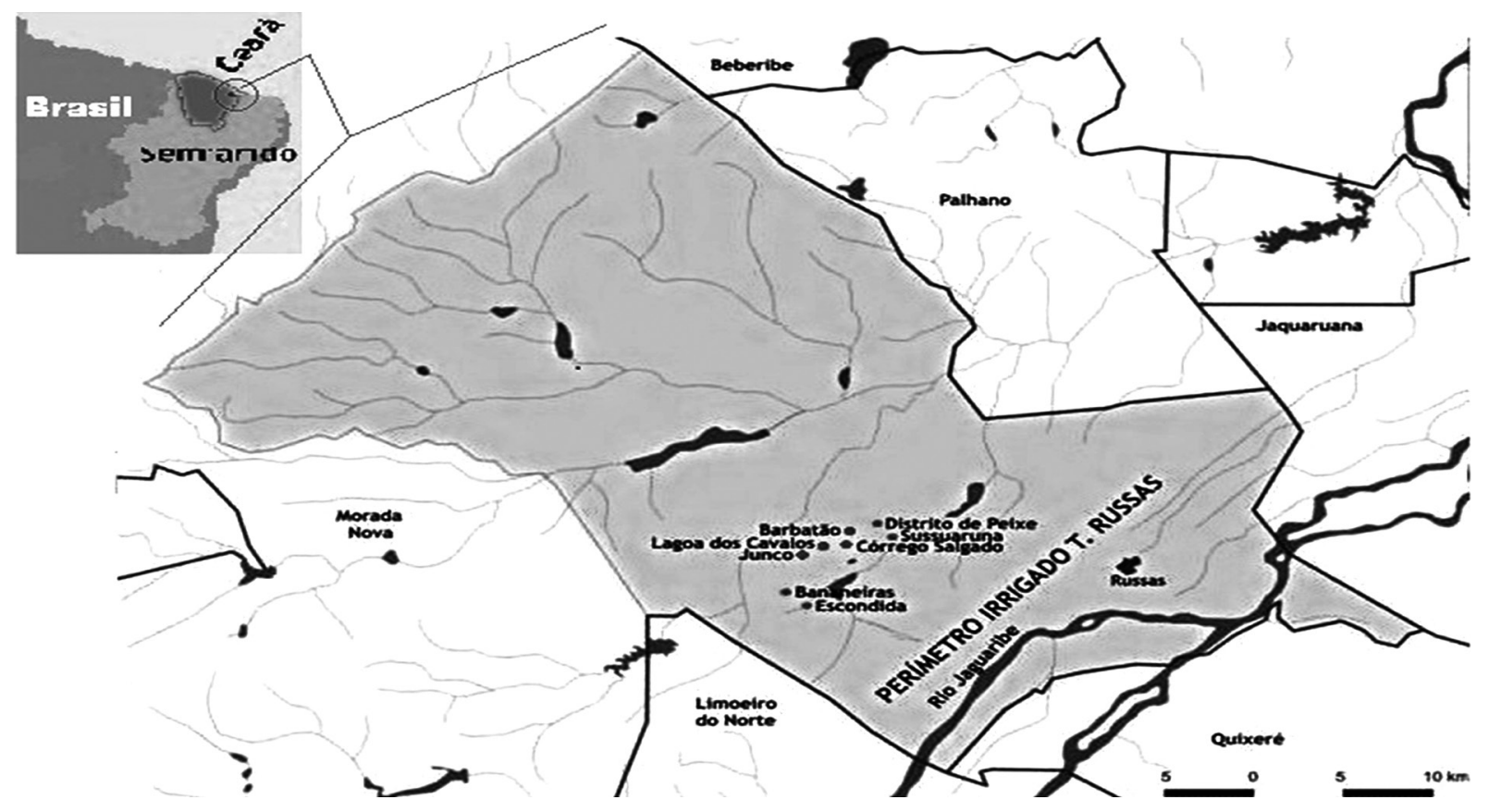

Fonte: Etene-BNB, a partir de dados do IBGE (Instituto Brasileiro de Geografia e Estatística).

Atualmente a população da comunidade é de 280 habitantes, distribuídos em 79 famílias ${ }^{5}$, uma média de 3,5 pessoas por domicílio. A população em idade economicamente ativa representa $74,3 \%$ do total. A maioria dos moradores é alfabetizada $(88,6 \%)$, alcançando a taxa de $92,9 \%$ entre as mulheres e $84,3 \%$ entre os homens. Entre os chefes de família, o total de analfabetos ainda é de $11,5 \%$.

A população de adolescentes e jovens com até 30 anos de idade chega a $53,6 \%$ do total. Entre os jovens, as mulheres representam $52,6 \%$ e, entre adolescentes, $43,1 \%$.

Em termos de ocupação da população, 82,3\% são agricultores familiares, enquanto $17,7 \%$ exercem atividades não agrícolas.

Os religiosos praticantes representam mais de $92 \%$ da população residente, dos quais $91,7 \%$

5. Família aqui tem o sentido de "família nuclear", ou seja, inclui somente as pessoas que vivem no mesmo domicílio. Em algumas passagens do texto será utilizado o termo "unidade familiar" ou "núcleo familiar", porém com o mesmo sentido. são católicos e 8,3\%, evangélicos. Não existe templo da Igreja Católica, apenas uma capela, onde é celebrada a missa durante a festa anual dedicada à padroeira local. A comunidade tem um templo da Igreja Assembleia de Deus, onde semanalmente são celebrados os cultos evangélicos.

As principais atividades pecuárias são a criação de bovinos e ovinos, com a utilização das soltas $^{6}$ remanescentes como área de pastoreio comunal durante o período de inverno (chuvas). É corriqueiro o uso do adjunto nas lavouras (milho, feijão), principalmente durante a broca, capina e colheita e no processo de produção da

6. O termo soltas ou terras soltas, conforme utilizado por Almeida (2009) para identificar uma das modalidades de uso comum da terra no Brasil, se originou durante a colonização e se refere às áreas não cercadas nessa região, uma espécie de terra sem apropriação privada, onde se colocam animais para o pastoreio comunal. Principalmente no período colonial, as áreas que viriam a denominar-se Lagoa dos Cavalos contavam com vastas áreas de terras soltas, perdendo espaço para os cercamentos ao longo dos anos, acelerando-se no início dos anos 2000, quando foi implantada a 1aㅡ etapa do Perímetro Irrigado Tabuleiro de Russas. 
414 - Ação Coletiva e Delegação de Poder no Semiárido Nordestino: papel de lideranças locais e assessores externos numa comunidade rural

farinha de mandioca. O adjunto, ou mutirão, é uma forma de ajuda mútua recíproca, caracterizada pela não contabilização de dias ou horas trabalhadas.

Os agricultores praticam também o extrativismo da carnaúba, coletam a castanha de caju e criam abelhas para a produção de mel.

As terras ocupadas pela comunidade são altamente fragmentadas. Os 19 imóveis rurais existentes estão distribuídos em 817 hectares, dos quais 17 têm área entre 1 e 30 hectares. Na média, existem 10,3 hectares por domicílio familiar na comunidade (817 hectares/79 famílias). Porém, 550 hectares desta área pertencem a uma única propriedade, terras de herança compartilhadas por 13 núcleos familiares. Enquanto nesse imóvel a área média por família é de 42,32 hectares (550 hectares/13 famílias), nas demais, essa média cai para 4,07 hectares por família (269 hectares/66 famílias).

Em meados dos anos 1980, se iniciou um processo de organização que tem permitido à população gerir coletivamente os recursos locais adotando estratégias que articulam novas formas coletivas de uso e gestão com modos preexistentes de uso comunal, associando-os sempre a práticas de convivência com a semiaridez $z^{7}$. A partir desse período formaram-se diversos grupos produtivos ("grupo de produtores", apicultura, casa de farinha, banco comunitário de sementes, horta comunitária, ovinocultura, sistemas agrossilvopastoril e agroflorestal, barragens subterrâneas), um grupo de jovens, dois grupos de microcrédito e uma associação comunitária.

Em maio de 2008 se instalou um conflito socioambiental, em decorrência da ameaça de expropriação dos moradores para expansão do Perímetro Irrigado Tabuleiro de Russas (PITR). O projeto do governo federal prevê a desapropriação de terras, integrando áreas dos municípios de Morada Nova, Limoeiro do Norte e Russas. Diante da ameaça, as lideranças locais passaram a

7. A proposta de convivência com o Semiárido estimula práticas produtivas apropriadas à semiaridez e de acordo com a cultura e os saberes locais. Busca resgatar a autonomia e a autoestima dos sertanejos, contrapondo-se à lógica assistencialista das políticas de combate à seca. dedicar grande parte do seu tempo e trabalho em busca de saídas para o conflito. Em nome da associação, contando com a assessoria do Sindicato de Trabalhadores e Trabalhadoras Rurais (STTR) de Russas e da ONG Cáritas, montaram uma estratégia de mobilização para unir forças e gerar poder de representação local. Convocaram as associações das demais comunidades atingidas e, em conjunto, criaram uma Comissão de Defesa e Negociação (CDN), formada por dois representantes de cada comunidade atingida, mais representantes da Cáritas Diocesana de Limoeiro do Norte, STTR de Russas, Paróquia de Russas, Diocese de Limoeiro do Norte, MST, Escritório Frei Tito, Fetraece, e Via Campesina.

Logo a CDN tornou-se um canal de interlocução entre a Comunidade e o poder público. Em função da aprendizagem sobre formas de lidar com os atores institucionais, a postura inicial de confronto das lideranças locais deu lugar ao diálogo e à negociação. Em consequência, conseguiu-se avanços em diversas frentes, com o atendimento de reivindicações iniciais e o surgimento de outras no decorrer do processo. Após cerca de quatro anos de intensas negociações, ao invés da expropriação, as famílias foram reassentadas dentro do PITR, forçando uma mudança na configuração inicial do projeto do DNOCS.

As lideranças locais estiveram sempre à frente de todas as manifestações de resistência e fizeram valer o seu poder de representação local. No entanto, a base é a história de organização. Construída a partir das expectativas e cultura locais, ao longo dos últimos 30 anos a organização favoreceu o surgimento e o fortalecimento de lideranças cujo poder de representação local se consolidou ao longo do tempo, conforme mostrado no item 4 .

\section{Ação coletiva e delegação de poder}

A formulação da expressão "tragédia dos comuns" por Hardin (1968) colocava como destino inevitável de recursos de uso comum a degradação massiva. $\mathrm{O}$ autor argumentava que, 
frente a situações dessa natureza, os indivíduos defenderiam preferencialmente seus interesses pessoais, tornando inviável a ação coletiva para a regulação do uso de tais recursos. A solução seria a privatização ou a manutenção dos recursos comuns sob a gestão direta do Estado, a quem caberia a imposição de regras de acesso e uso.

Três anos antes da publicação de Hardin, Olson (1999 [1965]) questionou a ideia de membros de grupos de interesses comuns agirem de forma voluntária para promover tais interesses. Este autor acredita que se os interesses individuais entram em contradição com os interesses do grupo, o indivíduo age em função da defesa dos seus interesses próprios. Como argumento principal, citou que os indivíduos têm pouca motivação para contribuir para uma ação coletiva se percebem que não podem ser excluídos do uso do recurso ou do benefício alcançado. Concluiu que seria necessário aplicar mecanismos de sanções ou incentivos externos para libertar os indivíduos dos dilemas sociais aos quais estariam presos e evitar a atuação dos free riders (aproveitadores ou caronas). Estes teriam mais oportunidade de expressar condutas individualistas quanto maior e impessoal o grupo e as circunstâncias em que os desvios não são percebidos ou cobrados pela coletividade.

Segundo Olson, os grupos pequenos tendem a ser mais coesos e, portanto, menos propensos à necessidade de aplicação de tais mecanismos. Dentre os fatores dessa coesão está o fato de o benefício ser dividido por um número igualmente reduzido de participantes, proporcionando mais ganhos pessoais que custos. Nos grupos numerosos, ao contrário, o indivíduo não se sente estimulado a cooperar, uma vez que o benefício da ação coletiva é diluído de maneira que pode se tornar inferior aos custos de participação. Enquanto no grupo pequeno a não participação de algum dos membros é facilmente percebida no resultado final, no grupo grande o impacto é pouco perceptível.

Outra questão importante abordada por Olson diz respeito à necessidade de formação hierárquica nos grupos de interesse e o papel que atribui às lideranças. Atuando como gestoras dos interesses dos participantes, as lideranças seriam as responsáveis pelas conquistas, em função do papel de incentivar ou coagir os membros dos grupos visando ao alcance dos objetivos desejados (OLSON, 1999 [1965]).

As análises de Hardin e Olson mostram o quanto é difícil para um grupo de indivíduos empreender a ação coletiva. Mas nem sempre os grupos se comportam da forma como preveem estes autores. Características fundamentais dos fenômenos sociais foram obscurecidas em suas análises. Eles desconsideraram que normas, valores ou padrões culturais podem criar condições que levam os indivíduos, sem a necessidade de sanções ou incentivos externos, a criarem e respeitarem acordos que viabilizam a ação coletiva.

Por exemplo, uma característica importante para o funcionamento dos grupos é sua homogeneidade em termos de antecedentes culturais, interesses e recursos (econômicos e políticos). Ela é fundamental para que a organização aconteça, de fato, porque se relaciona diretamente com o tamanho dos grupos. Estes últimos, quando maiores, tenderiam a se tornar heterogêneos, dificultando a comunicação interpessoal (McKEAN e OSTROM, 2001) e, por consequência, os acordos entre os membros. A importância da comunicação interpessoal está relacionada ao fato de permitir a cada um ter clareza quanto aos mecanismos e sanções, mas também sobre o comportamento dos outros e, por conseguinte, facilitar a pressão social para que cumpram os acordos (OSTROM, 1998). Estudos empíricos realizados por Ostrom [1985, 1990, 1998, 2001), Feeny et al. (2001) e Agrawal (2002), dentre outros, mostram diversas possibilidades.

A ação coletiva, como todas as atividades humanas, é dependente de formas de coordenação, produto de uma construção social que, por sua vez, requer um longo processo de organização. Ela acontece quando duas ou mais pessoas (relativamente autônomas, com recursos e capacidades particulares, comportamentos divergentes e contraditórios) se unem para alcançar objetivos comuns (CROZIER e FRIEDBEG, 1990). 
416 - Ação Coletiva e Delegação de Poder no Semiárido Nordestino: papel de lideranças locais e assessores externos numa comunidade rural

Dito de outra forma, a persistência da ação coletiva depende da capacidade do grupo de criar e manter regras durante sua construção e coordenação. Portanto, um ponto crucial para o êxito de qualquer ação coletiva é a capacidade das pessoas de entrarem em consensos, realizarem acordos que possibilitem seguir cooperando (OSTROM, 1990). Em síntese, os dilemas sociais inerentes à ação coletiva podem ser superados com a criação de regras formais e informais que interferem na ação coletiva e, por consequência, evitam a "tragédia dos comuns".

As regras, por sua vez, funcionam como mecanismos regularizadores das relações, inclusive de poder, em determinado grupo, por restringir a liberdade de ação dos indivíduos que delas participam. Nesse processo, os atores implicados delegam poderes e responsabilidades específicos a determinadas pessoas (ou grupos de pessoas) a fim de que os representem em seus interesses coletivos. Reconhecem nelas a existência de habilidade e competência para tal (LAZZARETTI e SABOURIN, 1999) sem, no entanto, excluir a sua própria responsabilidade pela delegação.

Para cumprir a contento o mandato para o qual determinado indivíduo (ou grupo) recebeu delegação, é preciso que assuma deveres equivalentes às responsabilidades. Ou seja, além de dispor das condições necessárias para o cumprimento, necessita de habilitação para tal e da real compreensão sobre o papel a desempenhar. Por outro lado, estes últimos passam a exercer uma autoridade sobre os demais, porque podem influenciar as regras e o trânsito das informações. $\mathrm{O}$ poder exercido por esses personagens, por sua vez, depende do uso que eles fazem da posição alcançada perante os demais e corresponde às fontes de incerteza a que estão submetidos estes últimos. De acordo com Crozier e Friedberg (1990), são quatro as fontes de poder: (1) originário do controle de uma competência (conhecimento) específica (especialização); (2) ligado às relações entre uma organização e seu contexto; (3) nascido do controle dos canais de comunicação e informação e (4) proveniente da existência e uso de regras organizacionais.
Friedberg (1993, p. 121) alerta sobre a importância do momento de definição do problema enfrentado pelos atores organizados, em torno do qual se travam intermináveis batalhas, por vezes, obscuras. Nesse momento, explica o autor, é que se define "[...] a pertinência das competências específicas, dos saberes práticos e das possibilidades de ação de que dispõem os diversos atores interessados no problema", caracterizando-se, então, como uma fonte de poder. Desta forma, os indivíduos que acumulam as competências e/ou saberes (lideranças/autoridades) necessários para conduzir a solução do problema exercem poderes sobre os demais e são reconhecidos socialmente dentro da rede de relações (SABOURIN, 2003). $\mathrm{Ou}$ seja, esses atores exercem um papel importante na definição dos problemas, mas também como mediadores entre os atores internos e destes com os agentes externos.

À medida que é construída a ação coletiva, os problemas se redefinem e os campos de interação se reorganizam. Nesse processo, o êxito das lideranças nas responsabilidades que thes são atribuídas está ligado a alguns atributos pessoais, conforme Sabourin (2003). Este autor se refere às lideranças como sendo pessoas dispostas a assumir riscos e que, em geral, acumulam atributos como facilidade de expressão, carisma pessoal, experiência de migração urbana, atuação militante nas estruturas da Igreja Católica, situação econômica mais ou menos estabilizada e, finalmente, com posição de intermediário político ou de cabo eleitoral.

Enquanto mediador, o líder de determinado grupo assegura o contato entre os dois mundos, serve de intérprete entre as duas lógicas, defende interesses e pode até transformar conflitos em negociação (MENDRAS, 1978). Por outro lado, o mediador conta com certo domínio da lógica do mundo exterior e detém algum controle sobre a circulação de informações entre os dois mundos. Tal condição lhe permite filtrar ou retardar informações em seu próprio benefício (FRIEDBERG, 1993) ou mesmo mudar o sentido e a utilidade de coisas e atos, muitas vezes tornando-os contraditórios num e noutro universo (MENDRAS, 1978). 
Pode acontecer de o poder sobre determinado grupo ser exercido por assessores externos, ao prestarem assessoria política, organizacional, técnica ou política. Nestes casos, o poder pode ter origem tanto no controle do conhecimento quanto nos canais de comunicação.

Assessores externos são definidos como pessoas externas a determinado grupo, portadoras de um conhecimento que lhes é particular e que, numa relação relativamente duradoura com referido grupo, oferecem uma "contribuição teórica própria” (AZIBEIRO, 2001, p. 5).

Por tratar-se de agentes externos ao grupo, os assessores podem apresentar visões de mundo e interesses diferentes, orientando-se por posturas que se firmam em função da sua origem, formação e concepções de conhecimento acumulados na trajetória de vida. Ou seja, é importante levar em conta que a lógica de ação do assessor muitas vezes é diferente da lógica dos assessorados, nem sempre havendo total concordância destes a respeito das propostas (RIBEIRO, 1992). Portanto, não se deve esquecer que mesmo comprometido com o processo de transformação social e manifestando a intenção de não interferir nas decisões do grupo de assessorados, o assessor pode tornar-se responsável por imposições e direcionamentos na organização.

Dessa forma, as relações que assessores estabelecem com assessorados se diferenciam. A forma de atuar de determinado assessor pode contribuir para que assessorados descubram e valorizem seu saber ou, ao contrário, desconsiderar a capacidade e o saber dos mesmos (FREIRE, 1987, p. 27), tornando-se detentor do poder de decisão (AZIBEIRO, 2001). Neste sentido, o conhecimento do assessor tanto pode ser usado em prol da libertação quanto da opressão do grupo de assessorados, dependendo do comportamento que este assume. Deste ponto de vista, intervenções externas poderão ser boas ou más para os grupos.

Por outro lado, dependendo do nível de organização, a postura das lideranças locais em relação aos agentes externos pode ser de autonomia, dependência ou negociação seletiva (SABOURIN, 2003). Dos três tipos mencionados, a dependência tem sido o mais comum na história do Nordeste. O coronel do passado pode estar travestido de político, técnico de instituições públicas, do sindicato ou mesmo de ONGs. Ele pode se utilizar das vantagens dos conhecimentos técnicos e da informação para exercer uma espécie de tutela sobre determinados grupos. Pode até mesmo lançar mão de subterfúgios para interferir na orientação das ações coletivas com o intuito de favorecer práticas paternalistas e clientelistas sobre os atores locais, cooptar ou privilegiar grupos que não representam efetivamente a maioria (SAYAGO, 2000). Ou seja, existe o risco de processos aparentemente democráticos servirem apenas de mecanismos para encobrir a reprodução de práticas nem sempre recomendáveis.

Porém, quanto mais conscientes estão os grupos sobre o processo, mais efetiva é sua participação; quanto maior o grau de organização, menores as possibilidades de manipulação, imposições e direcionamentos por parte de assessores externos.

\section{Delegação de poder em Lagoa dos Cavalos}

Os acordos e arranjos que sustentam a ação coletiva em Lagoa dos Cavalos têm sido fruto de uma construção social no sentido explicitado na seção três. Nessa construção, conflitos ocorrem, acordos se firmam e regras (formais e informais) se criam. Isso acontece sob a coordenação de lideranças reconhecidas socialmente por saberes práticos e competências específicas, a quem se delegam poder e responsabilidade.

Este estudo identificou pelo menos três tipos de lideranças internas eleitas pela comunidade para assumir responsabilidades requeridas pela organização local, aqui denominados de: a) coordenadores, dos três tipos, os únicos eleitos em assembleia para liderar os grupos produtivos em função de se destacarem pela habilidade e experiência que adquiriram no decorrer do tempo em relação às técnicas de desenvolvimento da atividade (p.e. apicultura, ovinocultura etc); 
418 - Ação Coletiva e Delegação de Poder no Semiárido Nordestino: papel de lideranças locais e assessores externos numa comunidade rural

b) especialistas, da mesma forma que os coordenadores, destacam-se por habilidades técnicas adquiridas no desenvolvimento das experiências dos grupos diferindo, porém, nas atribuições recebidas dos demais; c) mediadores são reconhecidos pelos saberes e competências políticas que acumularam enquanto lideranças, durante a trajetória de resistência da comunidade, seja na mediação dos conflitos internos e externos, seja na articulação externa em busca de projetos e apoios.

Mas o poder é delegado também a assessores externos como os do STTR (Sindicato de Trabalhadoras e Trabalhadores Rurais de Russas), da Empresa Estadual de Assistência Técnica (Ematerce) e da ONG Cáritas. A análise é apresentada nas duas subseções a seguir.

\subsection{As lideranças locais}

Os três tipos de lideranças percebidos em Lagoa dos Cavalos emergiram entre os próprios moradores, na base da organização local.

Coordenadores e especialistas podem ser associados ao "especialista" descrito por Crozier e Friedberg (1990), pois ao longo da trajetória desenvolveram habilidade e experiência particular em determinado assunto, técnica ou atividade e, por isso, são referência para os demais membros da comunidade. O monopólio individual do conhecimento daquilo que é de sua competência lhes permite manter certo controle sobre os demais membros do grupo, além de dificultar a sua substituição. Diferem entre si no tipo de responsabilidade que assumem, mas exercem atividades que se complementam na organização do funcionamento dos grupos produtivos: enquanto os coordenadores são responsáveis pela condução dos grupos produtivos, os especialistas, em geral mulheres, realizam tarefas específicas de apoio à ação dos coordenadores ou dos dirigentes da associação (elaboração de atas, sistematização de atividades, tesouraria e controle contábil dos grupos ou da associação comunitária ou organização de eventos, festas, dentre outros).

O coordenador de grupo é o indivíduo que organiza e orienta os trabalhos coletivos, no sentido de operacionalizar, fazer acontecer o trabalho de grupo. Sob sua responsabilidade, está também o controle da divisão de tarefas entre os membros e definição da época de sua execução, assim como a convocação no momento oportuno. Ele é também o responsável pela organização de calendários de trabalho nos grupos e convocação das reuniões mensais ou extraordinárias que acontecem entre membros de cada um.

Nos grupos em que a repartição dos resultados se realiza com base nos dias trabalhados, os coordenadores controlam as diárias de cada um dos membros e realizam a repartição final. Em todos eles, o coordenador é também o responsável por fazer cumprir os acordos coletivos e pela aplicação das sanções aos infratores.

Seguir regras se configura ao mesmo tempo como fonte e limitação de poder. Por isso, é fácil observar nos grupos os limites que o coordenador tem em sua margem de arbitrariedade. $\mathrm{O}$ fato de os grupos produtivos serem pequenos e homogêneos (componentes pertencem à mesma rede de relações, condições socioeconômicas semelhantes) facilita a comunicação entre os atores e o monitoramento (OSTROM, 2001) não só das ações de cada um dos associados, mas também do coordenador. Assim, todos sempre estarão pressionados a cumprir as regras acordadas coletivamente, inclusive o coordenador. Portanto, monitorar o comportamento de cada um dos participantes é também uma forma de limitar o poder do coordenador.

Coordenadores e especialistas participam das discussões e decisões que envolvem a comunidade e a associação comunitária, reproduzem o discurso político dos líderes mediadores e são incansáveis no trabalho de mobilização dos associados.

Já o grupo de mediadores é composto por lideranças com leque de ação mais amplo. Percebe-se neles o compromisso de doação, tanto no sentido material (tempo, trabalho) quanto intelectual e espiritual (saberes, habilidades, paixão, entusiasmo, coragem).

Enquanto mediadores, os líderes locais têm desempenhado papel decisivo nas conquistas da 
comunidade desde os anos 1980. Envolvem-se principalmente nas decisões estratégicas e na gestão das atividades da associação comunitária (sendo dirigentes ou não) e são efetivamente os responsáveis pela intermediação das relações entre os atores locais, os assessores e o mundo. Mais que isso, funcionam como verdadeiros intérpretes de ambas as lógicas para um e outro mundo, transformando conflitos em negociação (MENDRAS, 1978), a exemplo daquele provocado pela implantação do projeto de irrigação em suas terras. As origens e trajetórias de trabalho dos mediadores foram construídas na própria comunidade, permitindo-lhes conhecer a lógica e o vocabulário local. Isso facilita a tradução interna das informações absorvidas nas discussões externas, conforme se observa na fala a seguir:

Então, o conhecimento que a gente consegue nessas discussões mais amplas, por exemplo, a partir da luta, a gente consegue levar [para a comunidade]. [...] É buscar traduzir de uma forma que, pra mim, eu entenda aquilo que foi difícil talvez eu compreender, a partir das discussões mais amplas, mas eu comecei a encontrar uma nova forma de eu compreender. E aí, depois eu consigo traduzir para os outros. Acho que ajuda a vivência, por eu ser um deles. Talvez se eu fosse de fora, não seria tão fácil (Liderança D, setembro de 2010).

As vocações das lideranças se complementam na organização e no funcionamento dos grupos produtivos, na atração de "projetos", na articulação social e política, na participação em eventos e divulgação da ação coletiva local e das qualidades da comunidade. A compreensão dessa complementaridade nas funções dos mediadores é percebida na fala de informantes e das próprias lideranças. No entanto, as mesmas falas revelam preocupação com a concentração de informações em algumas pessoas, em função dos riscos embutidos. De fato, o controle dos canais de comunicação configura-se como fonte de poder das lideranças (CROZIER e FRIEDBERG, 1990) pois, com isso, poderão influenciar o trânsito das informações ou mesmo manipular o seu conteúdo.
Mas a verdade é que a maioria dos envolvidos nos grupos se esquiva da participação em eventos externos pelo receio de assumir a responsabilidade de repassar informações aos demais.

Corroborando a tese de Ostrom (1990), para prosseguir cooperando, os envolvidos na ação coletiva local criam e mantêm regras em funcionamento, não obrigatoriamente formais. Em relação às lideranças, por exemplo, ocorre a dispensa de tarefas quando a ausência se justifica pela participação em alguma atividade cuja responsabilidade lhes foi delegada pela comunidade. Esta é uma regra implicitamente reconhecida e aceita por todos os membros da associação e dos grupos produtivos.

Em alguns momentos - porque na nossa luta, a nossa tarefa é maior - nós somos dispensados se estamos numa atividade em prol da comunidade. Por exemplo, se eu estiver em Fortaleza participando de um encontro, ou qualquer outra atividade que seja relacionada ao trabalho comunitário, se houver alguma tarefa dos grupos durante este período, o grupo dispensa a minha presença, porque reconhece isso. Reconhece que nós estamos trabalhando em benefício da comunidade, num encontro A, B ou C, ou em qualquer atividade que seja relacionada ao trabalho comunitário (Liderança C, Abril, 2010).

Uma síntese da trajetória dos quatro principais mediadores locais é apresentada a seguir. O primeiro líder (líder $A$ ) surgiu em meados dos anos 1970, momento de eleição do primeiro representante local (delegado sindical) no STTR. Segundo ele, engajou-se no movimento sindical não por vontade própria, mas por imposição dos moradores da comunidade. Com o decorrer do tempo, foi tomando confiança e gosto pela coisa:

Eu comecei como delegado sindical em 76. Foram fazer uma votação e eu tirei os votos todos. Parece que houve uma história que combinaram e eu fiquei surpreso, porque eu era muito tímido, vergonhoso para esta história. Eu tinha 27 anos. Eu fui obrigado a aceitar. Aí eu comecei. E era um sofrimento. Na época 
420 - Ação Coletiva e Delegação de Poder no Semiárido Nordestino: papel de lideranças locais e assessores externos numa comunidade rural

tinha vergonha. Quando eu tinha duas semanas de delegado fui pra Brasília, um encontro com o Figueiredo. E foi a primeira viagem que eu fiz na minha vida (liderança $A$, setembro de 2010).

Posteriormente, em meados dos anos 1980, $A$ se fortaleceu em função de sua atuação decisiva na conquista do financiamento inicial para a comunidade e na organização do primeiro grupo produtivo ("grupo de produtores"). Na consecução desse projeto, foi fundamental o papel que este ator exerceu na mediação entre os agricultores e as instituições externas (STTR, bancos e empresa estadual de assistência técnica). No início dos anos 1990, A já cumpria seu primeiro mandato na direção do STTR do município de Russas. Em $A$ se observam atributos pessoais (SABOURIN, 2003) tais como a estabilidade econômica, principalmente em função de possuir terras que lhe permitem gerar renda e certa independência econômica. No entanto, tem dificuldade de realizar articulação política.

Quando $A$ assumiu a presidência do STTR, o líder $B$, que surgira no âmbito do "grupo de produtores", tomou seu lugar na função de delegado sindical, iniciando sua militância no STTR de Russas. No mandato posterior ao de $A$, a liderança $B$ ascendeu ao cargo de presidente do STTR, sendo eleito por seis mandatos de três anos (quatro como presidente, um como secretário geral e um como secretário de política), resultando em 18 anos a serviço do STTR.

Da mesma forma que $A$, o líder $B$ afirma que assumiu o cargo pela circunstância que se impôs naquele momento e não por opção própria. Exceto pelo fato de possuir terras próprias e situação econômica mais ou menos estabilizada, $B$ não é detentor dos atributos pessoais mencionados por Sabourin (2013) como importantes para o êxito da ação coletiva. Ao contrário, com atitudes pouco flexíveis politicamente, $B$ não possui carisma pessoal, é avesso a riscos e fechado a negociações.

O líder $A$ permaneceu fora da diretoria do sindicato por um mandato, mas retornou em seguida, em chapa composta também pelo líder $B$. No intervalo, $A$ compôs com $C$ uma chapa de oposição para disputar as eleições, em função da insatisfação de ambos com o relaxamento da diretoria em relação a ações favoráveis à comunidade e que, entendiam, era fruto da acomodação gerada pelos vários mandatos consecutivos. A disputa seria apenas uma forma de proporcionar aos associados um momento de reflexão e, à diretoria, a oportunidade de tomada de consciência sobre a necessidade de mudança de atitude. Tendo sido derrotada a chapa, no mandato seguinte $A$ e $C$ já compunham a chapa encabeçada por $B$.

A ascensão à direção do STTR e permanência por mandatos sucessivos, contribuiu para que os líderes $A$ e $B$ passassem a desfrutar de reconhecimento e legitimidade dos comunitários. Tornaram-se mediadores nas relações entre a associação e o STTR, exercendo papel fundamental nos diversos tipos de apoio que este viria a prestar à comunidade. Cite-se, como exemplo, a responsabilidade formal assumida em relação a projetos e financiamentos pleiteados por Lagoa dos Cavalos durante o período em que a ação coletiva local foi informal (sem a existência da figura jurídica da associação comunitária). Este último aspecto da contribuição dessas lideranças, enquanto dirigentes sindicais, é considerado relevante pela população local, visto que é recorrente no discurso de moradores e de demais lideranças, a exemplo da fala a seguir.

Quando o grupo ainda era informal, a gente conseguiu a energia, que foi o primeiro projeto através do sindicato. [...] E é muito bom termos pessoas que saíram da nossa organização. Saíram o companheiro $A$ e o companheiro $B$, que foram os pioneiros de nossa organização em Lagoa dos Cavalos (liderança $C$, setembro de 2010).

Mesmo retornando ao sindicato por mandatos consecutivos, $A$ e $B$ continuaram por algum tempo engajados nos grupos produtivos de Lagoas dos Cavalos, inclusive liberando suas terras para abrigar colmeias do grupo de apicultura, 
do qual eram membros. Desligaram-se quando o sindicato passou a requerer mais do seu tempo, conforme explica $A$ :

Não sou mais de nenhum grupo. Mas não faz tempo que a gente saiu. Era eu e B. A gente ficou até bem pouco tempo. E quando o sindicato começou a melhorar, a exigir mais da gente, tivemos que sair dos grupos. Só que é assim: tudo o que precisam da gente, de mim, do sindicato, a gente vai ajudando (liderança $A$, setembro de 2010).

O terceiro líder mediador (líder C) surgiu da mobilização pela organização de um grupo de jovens e de uma horta comunitária, em 1988, tendo sido o seu primeiro presidente. Esse personagem viria a se firmar como a referência central na comunidade a partir da segunda metade dos anos 1990, em função de vários atributos pessoais, inclusive a capacidade de articulação política. A fala a seguir expressa o reconhecimento social de que desfruta $C$ enquanto liderança comprometida e portadora de habilidades para articulação política em favor dos demais.

Quando C começou, foi de uma maneira que parece que tinha nascido para aquilo. Muito esforçado, com toda aquela disposição de levar os outros, de ver o lado comunitário, de incentivar os outros. [...] $C$ tem uma vantagem com ele, porque é uma pessoa que faz a coisa com convicção. Onde ele está, faz isso, porque é uma coisa natural dele. Em alguns momentos, ele tem muito mais facilidade de fazer esta parte de articulação política (liderança $A$, setembro de 2010).

Presidente da associação por vários mandatos, mesmo quando não responde por cargos de direção, $C$ permanece figurando como a principal referência no trato de problemas internos, mas principalmente de questões que requerem a articulação política e a mediação entre atores locais e agentes externos. Em função de sua vocação política e capacidade de articulação, tem sido também o principal representante local nos eventos externos nos quais a comunidade se faz representar.
A quarta liderança (líder D) é mulher e sua vocação revelou-se não no movimento sindical ou nos grupos produtivos, mas na organização da vida religiosa da comunidade, nos trabalhos de catequese da igreja católica. Ganhou experiência dentro do grupo de jovens, como presidente, realizando um trabalho de conscientização e engajamento de outros jovens na ação coletiva capitaneada pela associação local. Destacou-se durante a intervenção da Cáritas, na segunda metade dos anos 1990, ao ponto de, em 2004, forjar a formação de nove jovens do grupo em gerenciamento de água das cisternas de placa e em cidadania, para capacitar as famílias beneficiárias. Além da capacidade de articulação, sua fala revela nuances de seu posicionamento político em relação aos direitos de acesso à água do PITR e à necessidade de engajamento social dos jovens do lugar.

No P1MC existe a capacitação para o gerenciamento dos recursos hídricos. Mas no projeto da Cáritas não havia recursos para a formação. Era só para a construção das cisternas. Mas a gente achava importantíssimo que se pudesse discutir sobre a questão do direito e de como gerenciar a água. Naquela época a gente já falava no Projeto Tabuleiro de Russas. Então, tivemos essa formação e fizemos o trabalho de capacitação com as famílias. Isso começou a despertar nos jovens também o interesse pela vida social da comunidade (Liderança $\underline{D}$, setembro de 2010).

Em seguida, $D$ tornou-se monitora de cursos no âmbito do programa Um Milhão de Cisternas (P1MC) em diversas comunidades e municípios das redondezas, trabalho que durou cinco anos. Compõe a Comissão Municipal de Convivência com o Semiárido do Município de Russas ${ }^{8}$, divide com $C$ a representação da comunidade em eventos externos e, com as demais, a Comissão de

8. A proposta de Convivência com o Semiárido estimula práticas produtivas apropriadas à semiaridez e de acordo com a cultura e os saberes locais. Busca resgatar a autonomia e a autoestima dos sertanejos, contrapondo-se à lógica assistencialista das políticas de combate à seca. 
422 - Ação Coletiva e Delegação de Poder no Semiárido Nordestino: papel de lideranças locais e assessores externos numa comunidade rural

Defesa e Negociação (CDN). Num trecho de seu depoimento, $D$ relata detalhes de sua própria trajetória.

Na verdade, este meu trabalho com a comunidade e com os grupos e, posteriormente, com outros grupos, fora da comunidade, começou quando eu ingressei na vida religiosa a partir da catequese. Então, a base do trabalho com os grupos foi a catequese. Eu fiz a primeira eucaristia aos sete anos, sem entender o que significava. Só aos 10 anos eu vim perceber e compreender o sentido. Aí comecei a me interessar em passar aquilo que eu tinha aprendido para as crianças que estavam se preparando para fazer a primeira eucaristia, no sentido de perceber o significado do sacramento. Embora eu não estivesse associada na associação, comecei este trabalho com a associação. Dentro do grupo de jovens [como presidente], a gente começou nessa perspectiva também de que a gente pode estar contribuindo em parceria com a associação e a associação apoiando o grupo de jovens.

Ainda sobre $D$, merece destaque o trabalho na Cáritas Diocesana de Limoeiro do Norte desde meados dos anos 2000, através do qual presta assessoria às comunidades rurais e urbanas (catadores de lixo). Sua competência é ressaltada por $A$, ao tempo em que aponta as dificuldades enfrentadas na comunidade em função do seu afastamento.

$D$ é inspirada mesmo. Parece que já nasceu para aquilo. Tanto que ela deixou um vácuo muito grande em Lagoa dos Cavalos quando foi trabalhar na Cáritas. Porque a liderança, às vezes... as pessoas só confiam nela. E quanto mais você se dedica mais o povo aproveita. Porque na realidade a pessoa vai adquirindo mais experiência e cada dia vai fazendo a coisa mais fácil, tem convicção no que está fazendo. Ela saiu dali... fica até difícil em determinados momentos. É uma perda da comunidade (liderança $A$, setembro de 2010).

$\mathrm{O}$ acesso ao mundo exterior proporcionou, além do crescimento profissional, o contato e a aprendizagem com questões sociais e políticas que a atuação no âmbito da comunidade não permitia. Mas ela própria reconhece a importância da aprendizagem na comunidade, influenciada principalmente pelos precursores da organização local.

O trabalho que desenvolvo atualmente com catadores, devo à formação que eu tive na comunidade. E isso foi muito motivado pelas pessoas que já faziam o trabalho comunitário, na pessoa do líder $C$, na pessoa do líder $A$. Então, foi uma sementinha que foi regada por eles. Tudo isso eu devo muito à comunidade, a partir da atuação que eu tive lá (liderança $A$, setembro de 2010).

A abertura de portas para o contato com outros espaços, outras realidades e com o poder público, permitiram a $D$ compreender, de forma mais global, as problemáticas do mundo e sua relação com aquelas da própria comunidade. $\mathrm{O}$ conjunto de experiências vivenciadas por ela tem fornecido elementos que podem contribuir para o fortalecimento de propostas e argumentos a favor do local, mas também é fonte de poder. Porém, existem outros aspectos relativos ao seu afastamento da comunidade que devem ser considerados. Houve perda de poder, em função da redução de responsabilidades assumidas localmente. Por exemplo, no momento da pesquisa havia um processo de transição, no qual outros jovens paulatinamente assumiam responsabilidades antes delegadas a $D$, significando também a abertura de oportunidades para a revelação de outras.

Por outro lado, a ocupação de espaços no mundo exterior e, no caso específico, numa ONG, pode desencadear outras repercussões. Uma delas é a paulatina assimilação de outra visão de mundo e a consequente mudança de interesses, discurso e modo de ação, ou mesmo provocar uma tensão entre defender os interesses do grupo ou comunidade e assegurar o emprego. Isso é algo a ser verificado no futuro.

Cabe mencionar alguns atributos pessoais que caracterizam esses indivíduos, em alguns 
casos, aproximando-se daqueles propostos por Sabourin (2003). Destaca-se o discurso fácil, convincente e otimista, principalmente em $C$ e $D$. O otimismo aparece nos seus discursos que sempre mostram o lado positivo das situações com as quais os grupos locais se defrontam, mesmo quando acontecem em circunstâncias negativas. Atrelada ao otimismo, observa-se a capacidade de convencimento, pois é perceptível a motivação e o engajamento dos demais nos assuntos/projetos/eventos para os quais são chamados a discutir/participar. Ao mesmo tempo, são pessoas com flexibilidade e muita capacidade de mudança na forma de ver o mundo, sempre abertas à aprendizagem com os próprios erros e os dos outros.

Quanto à capacidade de entrarem em consenso e realizar acordos, como questão importante para a persistência da ação coletiva (OSTROM, 1990), as evidências apontam que $A, C$ e $D$, em particular, têm exercido papel fundamental para tal, dada a capacidade de lidar com a diversidade de visões e opiniões e de extrair das situações os pontos consensuais que permitem acordos e eliminam (ou minimizam) conflitos. O diferencial de Lagoa dos Cavalos, na opinião dos entrevistados, tem a ver com a presença de atributos como: vocação, otimismo, cautela, generosidade, humildade e capacidade de analisar as situações e os contextos, além do senso de grupo, de coletividade, impregnado na prática diária dessas lideranças. $\mathrm{O}$ conjunto desses atributos permitiria o seu reconhecimento (e legitimidade) dentro da comunidade.

Pode-se considerar, ainda, à luz do proposto por Sabourin (2003), que todas as lideranças têm relativa estabilidade econômica, porque dispõem de terras de herança, veículo pessoal (motocicleta), contando com familiares para eventual substituição nas tarefas dos grupos a que pertencem, quando se ausentam para participar de eventos ou reuniões.

Além do fato de que todos se envolvem diretamente nas atividades internas como membros dos grupos, das comissões e das redes, nenhuma das lideranças migrou alguma vez para centros urbanos. É perceptível, também, principalmente em $C$ e $D$, que a preocupação social ultrapassa a fronteira da comunidade, porque enxergam as conquistas sociais como resultados do trabalho coletivo num contexto mais amplo. No caso de $C$, é visível sua posição de intermediário político.

\subsection{Os assessores externos}

Assessores externos, representantes de diversas instituições públicas e da sociedade civil, têm atuado desde meados dos anos 1980 em Lagoa dos Cavalos, seja com apoio técnico, organizativo ou político.

O acesso da comunidade aos recursos (públicos ou de organizações da sociedade civil) para os investimentos realizados em infraestrutura e nos projetos produtivos e sociais, contou com o apoio do STTR, inclusive servindo de ponte entre os grupos locais e a empresa estadual de assistência técnica (Ematerce). Por sua vez, a Ematerce facilitou o acesso a recursos dos projetos São Vicente e São José, além de articular o apoio da ONG Esplar (Centro de Pesquisa e Assessoria) para implantar o Banco de Sementes Comunitário e da Embrapa, para o sistema agrosilvopastoril. A partir das articulações assessoradas pela Cáritas, os grupos chegaram ao BNB (Banco do Nordeste do Brasil), à Senaes (Secretaria Nacional de Economia Solidária) e à Obra Kolping ${ }^{9}$, em busca de recursos para investir na atividade apícola, e à Embrapa para conseguir apoio técnico na implantação de um projeto de ovinocultura.

A análise aqui realizada se prende à ação de assessores representantes das três instituições com presença marcante em Lagoa dos Cavalos, tanto do ponto de vista do tempo de intervenção quanto do apoio prestado no processo de organização local: STTR, Ematerce e Cáritas.

9. Instituição criada pela Igreja Católica alemã, com atuação no Brasil em ações visando o desenvolvimento de projetos sociais, de geração de renda, de capacitação profissional e para o exercício da cidadania de jovens e adultos (OBRA KOLPING, 2010). 
424 - Ação Coletiva e Delegação de Poder no Semiárido Nordestino: papel de lideranças locais e assessores externos numa comunidade rural

\subsubsection{Sindicato de Trabalhadores e Trabalhadoras Rurais (STTR)}

De acordo com Ribeiro (1992), os STTR geralmente prestam algum tipo de assessoria a associações de agricultores familiares, mesmo que seja de sindicalistas que saíram da base. Sindicatos e associações têm funções e responsabilidades distintas. Por prestarem serviços diversos e até complementares, não é incomum encontrar agricultores associados a ambos. Daí, a não ser que existam diferenças políticas entre um e outro, os sindicatos sempre terão destaque na assessoria das associações.

De fato, o STTR de Russas esteve presente em Lagoa dos Cavalos desde as primeiras intervenções em 1980. Inicialmente, assessorando com informações sobre programas e projetos disponíveis, permitiu aos moradores locais se aproximarem da Ematerce; posteriormente, assumindo a responsabilidade jurídica pelos financiamentos contraídos pela associação informal, tornou-se, ao lado da Ematerce, uma referência institucional importante para a organização local. Nesse processo, representantes sindicais oriundos da base (moradores da comunidade que se tornaram mediadores e cujas trajetórias já estão descritas em subitem anterior), exerceram papel fundamental.

Também no conflito socioambiental instalado a partir de 2008, o STTR exerceu papel importante durante a negociação, contribuindo principalmente na mediação entre a associação local e os órgãos externos. Foi um dos protagonistas na organização da Comissão de Defesa e Negociação (CDN), tornando-se, em seguida, membro efetivo no processo de negociação com o poder público. Nesse momento da ação do STTR merece destaque a mediação das quatro principais lideranças locais descritas no subitem 4.1, duas delas ( $A$ e $B$ ) atuando como representantes sindicais, uma (C) como representante da associação local e a outra (D) em nome da Cáritas.

Fundado em 1963, o STTR de Russas tem a mesma origem da maioria dos sindicatos rurais cearenses surgidos nesse período, tendo como foco principal a luta pela reforma agrária em vir- tude da influência do PCB (FETRAECE, 2010). Após o golpe militar de 1964, todos sofreram intervenção do governo federal, perdendo a autonomia e tendo os objetivos de sua ação reorientados de acordo com os novos interesses dos governantes do País. Numa espécie de cooptação dos dirigentes sindicais, o governo transferiu para os sindicatos a atribuição de prestar serviços aos trabalhadores rurais nas áreas de assistência médica e odontológica, além da responsabilidade de repassar os recursos do Funrural aos aposentados (FETRAECE, 2010). A postura reivindicatória anterior transformou-se em assistencialista, dissociando-se das questões políticas (LAZZARETTI e SABOURIN, 1999). Essa transformação da estrutura inicial dos sindicatos representou aumento de poder para dirigentes, principalmente o presidente, que a partir de então podia, inclusive, utilizá-lo para se manter no cargo por mandatos consecutivos.

No caso particular do STTR de Russas, o cargo de presidente foi ocupado pelo líder $B$ por quatro mandatos consecutivos. A mesma liderança exerceu, ainda, dois outros mandatos, respectivamente nos cargos de secretário geral e secretário de política. $\mathrm{O}$ aspecto positivo desse fato foi contribuir para a aproximação entre a comunidade e o sindicato. Porém, derivaram consequências negativas como a acumulação de poder em uma única pessoa e acomodação da mesma em relação às ações em prol dos representados. Do que se captou na pesquisa de campo, esta condição foi o motivo central de uma articulação empreendida por $A$ e $C$, resultando em confronto eleitoral. Lançou-se uma chapa de oposição em uma das eleições realizadas na década de 2000, conforme descrito no item 4.1. Contudo, a oposição foi derrotada e no pleito seguinte já havia uma composição entre ambos os grupos na chapa da situação, novamente eleita.

\subsubsection{Ematerce}

Os primeiros passos de Lagoa dos Cavalos em direção à organização local foram conduzidos pela Ematerce, em 1985, com uma proposta 
inicial de organização para o desenvolvimento econômico e social. Essa instituição foi também responsável por facilitar o acesso dos agricultores ao crédito rural, revelando-se importante a sua ação relativamente aos avanços alcançados pela comunidade. Daí a necessidade de se conhecer as propostas que amparam tais ações, o que requer uma compreensão do funcionamento da extensão rural pública brasileira.

O atual sistema público brasileiro de assistência técnica e extensão rural é composto pelas Ematers (Sistema Ater), empresas estaduais criadas em meados dos anos 1970, em substituição à Ancar (Associação Nordestina de Crédito e Assistência Rural), que funcionava desde o final dos anos 1940. Em sua origem, o Sistema Ater (Assistência Técnica e Extensão Rural) se caracteriza principalmente pela adoção de uma concepção "difusionista-produtivista", originária do pensamento dos americanos Berlo (1960) e Rogers (1962), nos anos 1960. Ao propor tal modelo, estes cientistas tinham a intenção de difundir inovações tecnológicas, objetivando promover o aumento da produção agrícola e a modernização do campo. Esta concepção supõe uma relação autoritária, na qual o extensionista, como fonte de conhecimento, deve persuadir os agricultores a aceitar pacotes tecnológicos, muitas vezes inadequados à sua realidade. Ao seguir este referencial, o extensionista rural adota a postura de desconsiderar o saber local, fazendo valer unicamente o seu ponto de vista.

Tal modelo sofreu sérias críticas nos anos 1970. Do debate empreendido em torno do tema, emergiu uma proposta alternativa, um modelo participativo, crítico e baseado no diálogo (FRIEDRICH, 1988), influenciado pelas ideias do educador Paulo Freire (FREIRE, 1983). Este autor argumentava que a extensão rural deve ser um processo dialógico entre extensionista e agricultor, de forma a permitir a reciprocidade e a troca de conhecimentos e não a transmissão de informações. Com base nessa proposta é que havia uma mudança do discurso oficial por ocasião da criação da Embrater (Empresa Brasileira de Assistência Técnica e Extensão Rural), nos anos
1970. Ali, a extensão pública apresentava uma linguagem inclusiva, na medida em que revelava a intenção de permitir ao homem do campo protagonizar as discussões sobre problemas e soluções de ordem técnica, econômica e social. Apesar disso, não houve mudança significativa na prática da extensão rural oficial.

Mais recentemente, no final de 2003, assistiu-se a um novo esforço de mudança na lógica de intervenção do sistema Ater, a partir do estabelecimento de uma Política Nacional de Assistência Técnica e Extensão Rural (Pnater), a nova Ater, cujas ações devem ser guiadas por um processo educativo e alicerçadas numa prática dialógica e no construtivismo (CAPORAL, 2003). Porém, a mudança continua insignificante na prática da extensão oficial. A maioria das intervenções ainda é pautada pelo método tradicional (CAPORAL e RAMOS, 2006), ou seja, o mesmo "difusionismo-produtivista" inaugural da extensão rural brasileira. Também na prática dos extensionistas ainda não se observam grandes avanços em relação à postura original. A não ser nos casos em que estes, em virtude da sua formação e concepções teóricas, assumem o diálogo e a valorização do saber local. Mas isso não é generalizado, pois as ações são localizadas. Avanço mais significativo é observado na prática de algumas ONGs progressistas.

Em Lagoa dos Cavalos, até meados dos anos 1980 nenhuma intervenção externa havia acontecido. Quando a Ematerce entrou em cena, em 1985, sequer as CEBs (Comunidades Eclesiais de Base) haviam passado por ali. Durante esse período (1985-1990), seus extensionistas foram os responsáveis pela assessoria local na organização dos grupos, elaboração e implantação dos primeiros projetos para obtenção de crédito, além das articulações para o acesso das CEBs à comunidade.

Depoimentos de técnicos da Ematerce e de moradores mostram que os mesmos exerceram influência na concepção e até na condução dos trabalhos durante a implantação dos projetos em Lagoa dos Cavalos. Porém, as relações durante o processo não foram meramente de difusão de pacotes tecnológicos. Houve uma interação entre os técnicos e os atores locais refletindo na 
426 - Ação Coletiva e Delegação de Poder no Semiárido Nordestino: papel de lideranças locais e assessores externos numa comunidade rural

apropriação dos conhecimentos gerados durante a intervenção. Por isso os projetos sofreram adaptações à realidade concreta dos grupos, permitindo que a maioria perdure até os dias atuais.

Além disso, a situação instalada serviu de alerta aos atores locais em termos da importância de agir coletivamente quando se buscam apoios externos (técnico, político, financeiro etc.). Perceberam, por exemplo, que à medida que se consolidava a organização e que havia reconhecimento externo sobre isso, mais fácil se tornava o acesso a outros apoios e a outras fontes de recursos.

Em síntese, os desdobramentos da intervenção inicial da Ematerce foram positivos, no sentido de que houve inovação técnica e aprendizagem principalmente em termos organizativos. No entanto, os resultados não são devidos a mudanças nas diretrizes de ação e apoio institucional. São mais uma função da visão de mundo e da militância dos extensionistas envolvidos, que permitiram aos moradores refletir sobre suas práticas e saberes, valorizando-as na implementação dos projetos.

Após 11 anos de ausência (1991-2001), em 2002 a Ematerce retomou suas atividades na comunidade. Desde então, suas ações têm sido pontuais, em função também do reduzido quadro de funcionários e do precário apoio institucional e logístico para os trabalhos de campo. Nessa época, a ação mais importante em Lagoa dos Cavalos já era a da Cáritas.

\subsubsection{Cáritas Brasileira}

A Cáritas Brasileira está presente em todo o Brasil ${ }^{10}$. Ao longo de sua trajetória, desenvolveu três modelos distintos de intervenção, evoluindo da caridade assistencial (até 1974) para a promoção humana (a partir da década de 1970, no contexto das CEBs) e, por fim, para a caridade libertadora (a partir da segunda metade dos

10. A Cáritas é uma rede internacional com sede em Roma. Está no Brasil desde 1956, sendo formada pela Cáritas Brasileira e escritórios que a representam por meio de uma rede de Cáritas Diocesanas. anos 1980) que é o modelo adotado atualmente (CÁRITAS BRASILEIRA, 1991; SOUZA, 2007).

A introdução do modelo caridade libertadora promoveu mudança no modo de perceber as origens da pobreza, a partir de então vista como fruto das estruturas de exploração culturais e econômicas. O modelo tem como base a "mística/espiritualidade cristã" imbuída dos valores e ideias da Teologia da Libertação.

A intervenção da Cáritas em Lagoa dos Cavalos se iniciou em 1995, com a implantação de um "Projeto-Piloto de Convivência com o Semiárido", no âmbito dos Projetos Alternativos Comunitários (PACs), inseridos no modelo de intervenção "caridade libertadora". Criados no início dos anos 1980, os PACs têm como premissas o acompanhamento dos projetos do ponto de vista organizativo e do desenvolvimento das atividades produtivas sustentáveis entre segmentos mais pobres da sociedade. Nos anos 1990, quando a Cáritas passou a integrar a rede da ASA-Brasil ${ }^{11}$, os PACs no Semiárido brasileiro passaram a adotar a perspectiva de convivência, assumindo também reivindicações por direitos econômicos, ambientais e pelo desenvolvimento local sustentável. Como consequência desse processo de mudanças, o programa avocou em seus trabalhos a abordagem da participação popular na política (BERTUCCI e SILVA, 2003).

Por esse tempo, avançavam entre as ONGs brasileiras as discussões sobre a necessidade de mudança no enfoque de intervenção no meio rural, em direção à concepção dialógica, como alternativa ao modelo praticado pelos órgãos oficiais de assistência técnica e extensão rural, ainda atrelado ao "difusionismo-produtivista".

Nos PACs, a proposta se traduzia na ideia de criar instrumentos de promoção do "empoderamento" individual e coletivo na vida

11. A ASA (Articulação do Semiárido) é formada por uma rede de instituições ligadas à sociedade civil e um dos atores principais na institucionalização do conceito de Convivência com o Semiárido. A denominação inicial de ASA-Paraíba (1993) mudou para ASA-Brasil em 1999. Em 2012 contava com a congregação de cerca de 750. 
comunitária $^{12}$. Os PACs seriam uma espécie de "escola de cidadania", capaz de proporcionar formação profissional e política aos seus integrantes, com o papel educativo de substituir a passividade de cunho assistencialista por busca de autonomia. Neste sentido, a execução e o gerenciamento dos projetos seriam de responsabilidade das comunidades (JARA, 1998). Com isso, as relações comunitárias seriam fortalecidas de forma a criar e viabilizar espaços coletivos de mobilização e organização (BERTUCCI e SILVA, 2003), distanciando-se, então, da proposta do "difusionismo-produtivista".

A ideia dos "Projetos-Piloto de Convivência com o Semiárido" surgiu na ocasião da avaliação dos PACs, realizada entre 1992 e 1994. A implantação de tais projetos seria uma forma de aperfeiçoar os PACs, na perspectiva de construir experiências significativas, capazes de disseminação. No processo de seleção, as comunidades alvo seriam aquelas com capacidade organizativa, articulação com os movimentos sociais e suporte de acompanhamento por parte de entidades locais (BERTUCCI e SILVA, 2003). Nesta perspectiva é que Lagoa dos Cavalos foi selecionada para servir de projeto-piloto.

A intervenção da Cáritas no local iniciou com a elaboração de um diagnóstico participativo, a sistematização e a devolução das informações coletadas ao grupo, a partir de oficinas para sua validação. Concluídas essas etapas, foi construído um plano denominado "Plano de Desenvolvimento Comunitário". Ressalta-se que a presença massiva dos moradores nas oficinas na etapa de diagnóstico não se repetiu durante a elaboração do plano.

A metodologia do trabalho na comunidade teve uma característica essencialmente dialógica (FREIRE, 1987), com a preocupação de provocar a interação entre assessores e atores locais. Por um lado, buscava utilizar as redes de relações sociais

12. Empoderamento aqui se refere à construção de uma base de poder no sentido de os indivíduos tomarem controle de suas próprias vidas, definirem suas próprias agendas com vontade e capacidade de influir nas tomadas de decisão (LEÓN, 1997). preexistentes (parentesco, compadrio, amizade, grupos produtivos etc.) como forma de aproximar os assessores dos moradores. Por outro, os trabalhos de oficina envolviam momentos de "mística, motivação e projeto político", nos quais os assessores estimulavam a autonomia do grupo em relação às parcerias e/ou entidades apoiadoras e relacionavam o projeto com a vida em família, em comunidade e na sociedade.

Ao discutirem sobre a metodologia de trabalho da Cáritas, Bertucci e Silva (2003) referem-se à adoção de uma mística, por meio da qual os assessores estimulariam o grupo de assessorados a alimentar a vivência da espiritualidade em grupo. Tal mística permitiria a manifestação de uma "espiritualidade libertadora", propulsora da mudança de vida pessoal e social dos integrantes dos projetos (BERTUCCI e SILVA, 2003) ${ }^{13}$.

De acordo com Burity (2002), apesar de continuarem existindo formas paternalistas e assistencialistas em organizações religiosas, a igreja e os movimentos religiosos têm grande potencial mobilizador, inclusive para instrumentalizar e viabilizar diversos tipos de projetos e ações. Os mediadores religiosos buscam sempre relacionar a religião, as crenças e técnicas dos grupos com os quais trabalham à estrutura religiosa mais geral da sociedade (WOLF, 1970).

Realmente, em seu depoimento o assessor da Cáritas admite que a "mística espiritualizada" adotada em seu trabalho permite-lhe aproximar-se da religiosidade e espiritualidade do agricultor e, com isso, falar sua linguagem, o que ajuda a criar vínculos e adquirir credibilidade, fundamentais para o sucesso do trabalho que desempenha.

Apesar do comprometimento dos assessores, existem riscos de imposições teóricas e ideológicas nos trabalhos de assessoria, em função de lógicas distintas entre assessores e assessora-

13. O Termo "Espiritualidade Libertadora" tem origem na Teologia da Libertação (TdL), surgida na América Latina durante os anos 1960. A espiritualidade da TdL, além de cristã, teria características específicas como uma dimensão mística e o compromisso com a política e a justiça social. Ou seja, ao mesmo tempo em que denuncia as injustiças, anuncia o Reino de Deus como forma de libertação dos indivíduos (CASALDÁLIGA, 2003). 
428 - Ação Coletiva e Delegação de Poder no Semiárido Nordestino: papel de lideranças locais e assessores externos numa comunidade rural

dos (RIBEIRO, 1992; AZIBEIRO, 2001). Porém, os assessores da Cáritas afirmam que não impunham projetos aos grupos, mas criavam as condições para que eles próprios refletissem e encontrassem alternativas. A elaboração do diagnóstico seria um dos instrumentos para tal, fomentada pela organização construída ao longo da trajetória da comunidade, traduzindo-se nas decisões autônomas a partir de reflexões coletivas. O encaminhamento das discussões na associação e nos grupos seria um reflexo dessa autonomia, já que, independente da presença de assessores, a responsabilidade pelas deliberações sempre foi dos atores locais. O elevado nível de organização local na comunidade e a participação ativa dos atores nos processos reduzem as possibilidades de imposição, manipulação e direcionamento das propostas por parte dos atores externos.

Os trabalhos da Cáritas na comunidade foram concluídos em 2004. Desde então, o seu apoio resume-se a assessorias pontuais, por solicitação do grupo, por exemplo, na intermediação entre os moradores locais e o poder público no conflito gerado em função do Projeto de Irrigação. Mas a Cáritas não está sozinha nesse apoio e, portanto, não detém o controle de todo o processo nas negociações entre o grupo e o órgão de governo.

Além disso, conforme depoimento de um técnico daquela entidade, Lagoa dos Cavalos é uma comunidade que já trabalhou a sustentabilidade, além de ter autonomia, organização e capacidade para andar com suas próprias pernas.

Outros apoios, em momentos distintos da organização local, têm sido prestados à associação e aos grupos que, por sua vez, recebem de bom grado as propostas de melhorias que chegam à comunidade.

\section{Considerações finais}

Delegação de poder e de responsabilidade a lideranças locais e a assessores externos tem tido um papel fundamental na persistência da ação coletiva em Lagoa dos Cavalos.
Em relação às lideranças locais, nas atividades locais o poder é delegado aos especialistas, em função de habilidades e experiência particular nas atividades. Os especialistas exercem o papel de coordenadores de grupos ou de auxiliares destes em tarefas de controle; o poder é delegado também a algumas lideranças locais, sendo estas as que assumem a responsabilidade pela condução da Associação Comunitária e a mediação entre o local, os assessores externos e o mundo.

Mas a organização local não é dependente da capacidade ou habilidade de uma única liderança a quem os demais delegam poder e responsabilidade. Além disso, a ação de tais lideranças envolve o compromisso de doar-se para a comunidade, não apenas no sentido material, mas também intelectual e espiritual. Deste modo, são minimizados os perigos de uso de poder e domínio por parte de determinada liderança em benefício próprio.

Por outro lado, existe uma complementaridade nos papéis e habilidades das diversas lideranças. Isso ajuda na coordenação dos trabalhos dos grupos, fortalece a organização como um todo, além de facilitar a obtenção e diversificação de recursos, apoio técnico e político, importantes para a continuidade de seus projetos. Da mesma forma, auxilia no acesso a informações fundamentais para adaptar/melhorar o desenvolvimento das atividades, assim como permite que se firmem alianças com agentes externos sem perda da relativa autonomia em relação a conteúdos e formas de operacionalizar as propostas.

Cabe observar que existe um círculo virtuoso em torno das lideranças locais. A representatividade e legitimidade das primeiras lideranças, associadas ao êxito nos pleitos e projetos locais, proporcionaram o surgimento de novas lideranças, que por sua vez tornaram-se referência para os jovens, permitindo que alguns deles despertem e se aventurem a trilhar caminho semelhante, dando prosseguimento ao projeto coletivo da comunidade.

É verdade que parte das informações oriundas do mundo exterior ainda tende a se concentrar nas lideranças, porque participam de 
encontros, audiências e outros eventos externos. A maioria dos membros dos grupos e da associação se esquiva dos trabalhos de representação.

Quanto aos assessores externos, sua presença e apoio têm sido marcantes na comunidade desde o início de sua mobilização para a ação coletiva. Por lá passaram diversas instituições públicas e da sociedade civil, sendo o STTR, a Ematerce e a Cáritas as mais importantes do ponto de vista da contribuição para a organização local.

Tais intervenções aconteceram no contexto de um processo em construção, pois à medida que a organização se fortalecia, surgiam novas demandas e agentes externos se aproximavam com novas propostas, contribuindo para a consolidação da organização do grupo, o reconhecimento externo e, com isso, atraindo novos projetos. Neste sentido, é visível que a trajetória de organização ensinou aos moradores locais sobre a importância de diversificar as fontes de apoio, como forma de manter a relativa autonomia, limitando as relações de dominação que podem surgir no processo de intervenção de agentes externos.

Sobre este aspecto, não é demais lembrar que, de maneira geral, nos anos recentes o Sertão tem sido palco de uma disputa entre a Igreja, os sindicatos e as ONGs, pela hegemonia na defesa dos agricultores e pelo papel de intermediário entre estes e o Estado. A despeito de tais disputas, os assessores externos têm tido papel importante no apoio técnico e político a esses agricultores, principalmente quando os últimos conseguem articulação em níveis institucionais diversos, como se observa em Lagoa dos Cavalos.

Em Lagoa dos Cavalos, a relação das lideranças locais com os assessores em geral tem se caracterizado por uma postura de certa autonomia, de modo a preservar a independência. Tal postura, no entanto, não tem se configurado como obstáculo para que se firmem alianças com os assessores externos. Como mostrado nas análises, eles têm conseguido o acesso a informações, recursos, apoio técnico e empreendido negociações (por exemplo, no conflito envolvendo o PITR) que, sozinhos, não teriam o poder de conseguir.

Além disso, as lideranças locais têm consciência sobre a importância de manter uma boa reputação para gozar de respeito das instituições externas, principalmente daquelas que os apoiam financeiramente. Por isso, os compromissos assumidos são aqueles que, do ponto de vista do grupo, podem ser cumpridos. Cabe advertir, no entanto, que apesar do papel importante que assessores externos e lideranças locais têm no desenvolvimento da comunidade, a base se encontra mesmo na organização local. Ao criar mecanismos que facilitam a construção da cooperação e da coordenação dos atores envolvidos, a organização fortalece o grupo, estimula o surgimento de lideranças, atrai assessores externos e permite assegurar a sustentabilidade de suas ações coletivas.

Ressalta-se, finalmente, que Lagoa dos Cavalos é apenas um microcosmo dentro da complexa teia de situações que marcam a realidade do Semiárido nordestino. O estudo mostrou que, pelo seu caráter singular, o caso representa uma referência relevante para o entendimento e o avanço de formas de operacionalização de estratégias de desenvolvimento em nível local, que fogem aos vícios usuais na região. Tendências como paternalismo, baixa legitimidade das lideranças e falta de sentimento de pertencimento das ações coletivas pelas comunidades podem ser minoradas, quando as iniciativas e sua gestão têm fundamento na vontade e nos interesses das pessoas envolvidas. Essa questão serve de referência tanto para debates teóricos quanto para decisões de políticas públicas. Novos estudos que verifiquem os mesmos problemas em outros contextos poderão indicar até que ponto a comunidade estudada é apenas um caso isolado, bem particular e, portanto, não passível de generalização. Em todo o caso, as lições poderão inspirar processos mais condizentes com as realidades culturais e institucionais locais. 
430 - Ação Coletiva e Delegação de Poder no Semiárido Nordestino: papel de lideranças locais e assessores externos numa comunidade rural

\section{Referências}

ALMEIDA, A. Terras de preto, terras de santo, terras de índio: uso comum e conflito. In: GODOI, E. P. de, MENEZES, M. A. de e MARIN, R. A. (Orgs.). Diversidade do campesinato: expressões e categorias, v. 2: estratégias de reprodução social. São Paulo: Editora UNESP; Brasília, DF: NEAD, 2009. pp. 39-66.

AZIBEIRO, N. E. Educação popular e movimentos sociais: o que têm feito as assessorias? In: 24 REUNIÃO ANUAL DA ANPED: Intelectuais, conhecimento e espaço público, 24, Anais... Caxambu, 2001 (CD Rom).

BERLO, D. K. O processo de comunicação. Rio de Janeiro: Fundo de Cultura, 1960.

BERTUCCI, A. de A. e SLIVA, R. M. da S. Vinte anos de economia popular solidária: trajetória da Cáritas Brasileira dos PACs à EPS. Brasília: Cáritas Brasileira, 2003.

BURITY, J. A. Identidade e política no campo religioso: estudos sobre cultura, pluralismo e o novo ativismo eclesial. Recife: Universitária da UFPE, 1997.

CAPORAL, F. R. Bases Para uma Nova Ater Pública. 2003. Disponível em: < http://www.mda.gov.br/dotlrn/ clubs/redestematicasdeater/formaodeagentesdeater/ contents/photoflow-view/content-view?object id $=885745>$. Acesso em: 25 set. 2011.

CAPORAL, F. R. e RAMOS, L. de F. Da extensão rural convencional à extensão rural para o desenvolvimento sustentável: enfrentar desafios para romper a inércia. 2006. Disponível em: <http://www.pronaf.gov.br/ dater/arquivos/0730612230.pdf $>$. Acesso em: 05 set. 2011.

CÁRITAS BRASILEIRA. Mística e metodologia da caridade libertadora. Edições Loyola, 1991.

CASAlDÁligA, P. Nossa espiritualidade. São Paulo: Editora Paulus, 2003.

COSTA NETO, P. L. Estatística. São Paulo: Editora Blücher Ltda, 1977.

COUTINHO, C. P. Metodologia de investigação em ciências sociais e humanas: teoria e prática. Coimbra: Almedina, 2011.

CROLL, P. La observación sistemática en el aula. Madrid: Muralla, 1995.

CROZIER, M. e FRIEDBERG, E. El actor y el sistema: las restricciones de la acción colectiva. Cidade do México: Alianza Editorial Mexicana, 1990.

FETRAECE (Federação dos Trabalhadores e Trabalhadoras na agricultura do Estado do Ceará).
Curso estadual de formação político sindical. Fortaleza: ENFOC, 2010.

FREIRE, P. Extensão ou comunicação? Rio de Janeiro: Paz e Terra, 1983. (O Mundo, Hoje, v. 24).

. Pedagogia do oprimido. Rio de Janeiro: Paz e Terra. 1987. 17 ed. (O mundo, hoje, v. 21).

FRIEDBERG, E. O poder e a regra: dinâmicas da acção organizada. Tradução: A. P. da Silva. Lisboa: Edições Piaget, 1993.

FRIEDRICH, O. A. Comunicação rural: proposição crítica de uma nova concepção. 2. ed. Brasília: Embrater, 1988.

HARDIN, G. The tragedy of the commons. Science, v. 162, p. 1243-1248, 1968.

JARA, C. J. A sustentabilidade do desenvolvimento local. Desafios de um processo em construção. Brasília: IICA / Recife: Seplan-PE, 1998.

LAZZARETTI, M. A. e SABOURIN, E. Representação e construção da ação coletiva nos sindicatos rurais. In: CONGRESSO BRASILEIRO DE ECONOMIA E SOCIOLOGIA, 1999.

LEÓN, M. El Empoderamiento en la teoria y práctica del feminismo. In: LEÓN, M. (Org.). Poder y empoderamiento de las mujeres. Santafé de Bogotá: TM Editores: 1997.

MARCONI, M. A. e LAKATOS, E. M. Técnicas de pesquisa. 2. ed. São Paulo: Editora Atlas, 1990.

McKEAN, M. A. e OSTROM, E. Regimes de propriedade comum em florestas: somente uma relíquia do passado? In: DIEGUES, A. C. e MOREIRA, A. de C. C. (Orgs.). Espaços e recursos de uso comum. São Paulo: NUPAUB-USP, 2001. pp.79-95.

MENDRAS, H. Sociedades camponesas. Tradução: Maria José da Silveira Lindoso. Rio de Janeiro: Zahar, 1978.

OBRA KOLPING. História. São Paulo: Obra Kolping, 2010. Disponível em: <http://kolping.org.br/site/ institucional/historia > . Acesso em: 16 dez. 2011.

OLSON, M. A lógica da ação coletiva. Os benefícios públicos e uma teoria dos grupos sociais. Tradução: Fábio Fernandez. São Paulo: Editora da Universidade de São Paulo, 1999.

OSTROM, E. Institutional arrangements for resolving the commons dilemma: some contending approaches. 46th National Conference of the American Society for Public Administration, March 23-27, 1985. Indianapolis, Indiana. Disponível em: <http:/hdl.handle. net/10535/2274>. Acesso em: 16 nov. 2011. 
- Governing the commons: the evolution of institutions for collective action. Cambridge, New York: Cambridge University Press, 1990.

Crafting institutions for self-governing irrigation systems. San Francisco: Institute For Contemporary Studies, 1992.

A behavioral approach to the rational choice theory of collective action. American Political Science Review, v. 92, n. 1, p. 1-25, 1998.

Collective Action and the Evolution of Social Norms. The Journal of Economic Perspectives, v. 14, n. 3, p. 137-158, 1 jul. 2000.

Reformulating the commons. In: BURGER, J. et al. (Eds.). Protecting the commons: a framework for resource management in the Americas. Washington, D. C., Island Press, 2001. p. 17-41.

RIBEIRO, E. M. Fazenda Pica Pau, Miradouro, Minas Gerais: estudo sobre a família, o trabalho e a reprodução de agricultores familiares da Zona da Mata de Minas Gerais. Belo Horizonte-MG, 1992. 112p. (Mimeo).

ROGERS, E. M. Diffusion of innovations. New York: The Free Press, 1962. Disponível em: <http://books. google.com.br/books?hl=pt-BR\&lr $=\&$ id $=$ v1ii4QsB 7jIC\&oi $=$ fnd\&pg $=$ PR15\&dq $=$ Everett + Rogers\&ot $\mathrm{s}=$ DJUryKQt9V\&sig $=8 \mathrm{NJwErS6k7q-vR-dJNjAZO-}$
$9 \mathrm{~B} 0 \mathrm{~s} \# \mathrm{v}=$ onepage $\& \mathrm{q}=$ Everett $\% 20$ Rogers $\& \mathrm{f}=$ false $>$. Acesso em: 12 dez. 2011.

SABOURIN, E. Mudanças sociais, organização dos produtores e intervenção externa. In: CARON, P. e SABOURIN, E. (Eds.). Camponeses do sertão: mutação das agriculturas familiares no Nordeste do Brasil. Brasília: Embrapa Informação Tecnológica, 2003. pp. 145-178.

SAYAGO, D. A Invenção Burocrática da Participação: discursos e práticas no Ceará. Brasília: UnB. Tese (Doutorado em Sociologia), 2000.

SOUZA, A. R. de. Entre a assistência e a auto-gestão: a economia popular solidária na Cáritas. Revista Nures, n. 5, jan./abr. 2007. Disponível em: <http://www. pucusp.br/revistanures>. Acesso em: 15 jan. 2010.

SOUZA, D. V de e ZIONI, F. Novas perspectivas de análise em investigações sobre meio ambiente: a teoria das representações sociais e a técnica qualitativa da triangulação de dados. Saúde e Sociedade, v. 12, n. 2, p. 76-85, jul-dez. 2003.

TRIVIÑOS, A. N. S. Introdução à pesquisa em ciências sociais: a pesquisa qualitativa em educação. São Paulo: Atlas, 1987.

WOLF, E. Sociedades camponesas. Rio de Janeiro: Zahar, 1970. 
